Ministerstwo Nauki

i Szkolnictwa Wyższego

Digitalizacja archiwalnych numerów czasopisma naukowego Analecta Cracoviensia 1-24 (1969-1992)

i ich publikacja w otwartym dostępie - zadanie finansowane w ramach umowy 672/P-DUN/2017 ze środków

Ministra Nauki i Szkolnictwa Wyższego przeznaczonych na działalność upowszechniającą naukę

\title{
PAPIESKIE ZATWIERDZENIA FUNDACJI UNIWERSYTETÓW ŚRODKOWOEUROPEJSKICH W LATACH $1347-\mathrm{3} 386$ *
}

Pierwsze europejskie uniwersytety powstają w Bolonii i w Paryżu w XII wieku. Za wzorem tych miast poszły wkrótce inne we Włoszech i Francji. Myśl ta z kolei rozciąga się poza granice tych państw; powstają uniwersytety w Anglii, Hîszpanii i Portugalii. W 1347 roku powstaje uniwersytet w Pradze, pierwszy w środkowej Europie. Śladem państwa czeskiego podążyły inne państwa środkowoeuropejskie. Powstają uniwersytety w Polsce, Austrii, na Węgrzech, a następnie cały szereg studiów generalnych w Niemczech.

Przeglądając dokumenty dotyczące zakładania uniwersytetów środkowoeuropejskich, a w szczególności ich papieskie zatwierdzenia, zwróciłem uwagę na duże podobieństwo między papieskimi dokumentami.

Moja praca jest próbą dania odpowiedzi na pytanie, jakie podobieństwa i różnice istniały w procesie powstawania uniwersytetów środkowoeuropejskich. Punktem wyjścia dla tych rozważań stały się papieskie zatwierdzenia fundacji uniwersytetów. Oparłem się wobec tego tylko na samych tekstach źródłowych, nie korzystając z żadnej innej literatury.

\section{USTALENIE ZWIAZZKU GENETYCZNEGO}

W XIV wieku powstają w środkowej Europie uniwersytety. Pierwszy, układając je w porządku chronologicznym według daty wystawienia papieskich zatwierdzeń, to uniwersytet w Pradze z 1347 r., a następnie w Krakowie - 1364 r., we Wiedniu - 1365 r., w Pécsu - 1367 r.,

* Artykul Andrzeja Partyki - zmarłego w 1976 roku ucznia prof. A. Vetulaniego - został opracowany przez Autora w r. 1964 i wówezas to uzyskal bardzo wysoką ocenę prof. Vetulaniego. Publikowany obecnie tekst nie stracił i dziś swoich wartości poznawczych mimo ukazania się w r. 1970 monografii pióra Adama Vetulaniego n/t Początków najstarszych wszechnic europejskich.

$\mathrm{Z}$ uwagi na to, że Autor nie mógł już wprowadzić żadnych zmian czy poprawek do nowej wersji swojej rozprawy, przeto ogłaszamy ja drukiem na prawach rękopisu uporządkowanego od strony stylistycznej i graficznej przez p. R. Zawadzkiego. 
Erfurcie - 1379 i 1389 roku, w Heidelbergu z 1385 r., Chełmnie 1386 r., Kolonii - 1388 r. i w Budzie z 1389 i 1395 roku.

Badając papieskie zatwierdzenia uniwersytetów ograniczyłem się do dokumentów wystawionych przez papieży: Klemensa VI (1342-1352), Urbana V (1362 - 1370) i Urbana VI (1379-1389). Ze względu na trudności w uzyskaniu tekstu źródłowego papieskiego zatwierdzania uniwersytetu w Kolonii oraz, że obydwa zatwierdzenia dla uniwersytetu w Budzie wydał papież Bonifacy IX, nie uwzględniłem tych dokumentów w moim porównaniu papieskich zatwierdzeń uniwersytetów.

Wszystkie dokumenty papieskie wyrażające zgodę na powstanie uniwersytetów są do siebie bardzo zbliżone. Wyjątek stanowią dwa zatwierdzenia dotyczące uniwersytetu erfurckiego. Pierwsze zatwierdzenie wystawione zostało przez antypapieża Klemensa VII w dniu 18 września 1379 r., drugie wydane zostało przez papieża Urbana VI w dniu 4 maja 1389 r. i wzoruje się na pierwszym zatwierdzeniu. Ze względu na zasadniczą rozbieżność w redakcji tekstu Klemensa VII, przejętą później przez Urbana VI, nie przedstawiłem tych dokumentów w dalszych wywodach. Nie brałem ponadto pod uwagę późniejszych losów poszczególnych uniwersytetów. Interesowały mnie bowiem tylko papieskie zatwierdzenia.

Papieska zgoda na działanie danego studium generale występuje przed lub po dokumencie fundatora. W dwóch wypadkach posiadamy tylko papieskie dokumenty, a mianowicie odnośnie uniwersytetów w Pécsu i Chełmnie. Zbierając posiadane dokumenty dotyczące powstawania poszczególnych uczelni otrzymamy następujące zestawienie:

PRAGA

- 1. Papieskie zatwierdzenie wydane przez Klemensa VI w dniu 26 stycznia $1347 \mathrm{r}$.

KRAKOW - 1. Akt fundacyjny króla Kazimierza wystawiony 12 maja $1364 \mathrm{r}$.

WIEDEŃ

- 1. Akt fundacyjny książąt austriackich Rudolfa IV, Albrechta III i Leopolda III wystawiony 12 marca $1365 \mathrm{r}$.

PÉCS - Papieskie zatwierdzenie wydane przez Urbana $V$ w dniu 1 września $1367 \mathrm{r}$.

HEIDELBERG - 1. Papieskie zatwierdzenie wydane przez Urbana VI w dniu 23 października $1385 \mathrm{r}$.

CHEEMNO - Papieskie zatwierdzenie wydane przez Urbana VI w dniu 9 lutego $1386 \mathrm{r}$.
2. Akt fundacyjny króla Karola IV wystawiony $7 \mathrm{kwie}$ tnia $1348 \mathrm{r}$.

2. Papieskie zatwierdzenie wydane przez Urbana V w dniu 1 września $1364 \mathrm{r}$.

2. Papieskie zatwierdzenie wydane przez Urbana V w dniu 1 września $1364 \mathrm{r}$.

2. Akt fundacyjny księcia Bawarii Ruperta wystawiony 1 października $1386 \mathrm{r}$. 
Nie wiadomo tylko, czy brak aktów fundacyjnych dla uniwersytetu w Pécsu i Chełmnie nie został spowodowany tym, że po prostu nie zachowały się one do dnia dzisiejszego lub też w ogóle nie zostały nigdy wystawione. Jak bowiem zobaczymy, bulla papieża Urbana V dla uniwersytetu w Pécsu była poprzedzona takim aktem. Jest również rzeczą charakterystyczną, że obydwa uniwersytety, co do których nie posiadamy dokumentów fundatorów, albo nigdy nie powstały, jak uniwersytet $\mathrm{w}$ Chełmnie, albo też mamy poważne wątpliwości co do uruchomienia w tym czasie także studium generale, jak w Pécsu rzekomo już w czasach Ludwika. Przecież do dnia dzisiejszego uniwersytet w Pécsu posiada tylko wydział prawa.

Należy również zaznaczyć, że akt fundacyjny Kazimierza Wielkiego z dnia 12 maja $1364 \mathrm{r}$. nie jest pierwszym dokumentem związanym z zabiegami polskiego monarchy o założenie uniwersytetu krakowskiego. Pierwszym aktem zachowanym do naszych czasów jest suplika królewska ${ }^{1}$. Suplika ta, czyli pisemna prośba została wciągnięta do rejestrów papieskich dnia 6 kwietnia 1363 r. Jak dobrze wiadomo, prosił w niej król Kazimierz między innymi o wyrażenie zgody na założenie studium generale w Krakowie. Można przypuszczać, iż suplika ta jest tylko prośbą ogólną, zestawieniem wszystkich aktualnych próśb monarchy. Oprócz tego do każdego punktu supliki były zapewne dołączone prośby szczegółowe, które w sposób wyczerpujący omawiały każdy punkt supliki ogólnej. Ponadto wśród dokumentów dotyczących założenia uniwersytetu krakowskiego znajdujemy list papieża Urbana $\mathrm{V}$ do ówczesnego arcybiskupa gnieźnieńskiego Jarosława Bogorii Skotnickiego, opatrzony datą 16 października 1363 r. W liście tym papież domaga się od arcy.. biskupa gnieźnieńskiego przesłania do Awinionu m. in. dokumentu królewskiego i miejskiego, aby mógł poznać przywileje i swobody mającego powstać studium generalnego. W 1362 roku król Kazimierz wysyła poselstwo do Avinionu, które zawiozło suplikę królewską, a na pewno również ustnie przedstawiło i uzasadniło królewskie prośby. Papieżowi nie wystarczyła jednak suplika, nie wystarczyły zapewnienia królewskich posłów, skoro we wspomnianym liście do abpa Bogorii żądał przedłożenia kurii rzymskiej praw i przywilejów zamierzonego uniwersytetu. Wobec tego akt fundacyjny Kazimierza Wielkiego i dyplom miasta Krakowa opatrzone tą samą datą: 12 maja 1364 r., należy traktować jako wydane na żądanie papieskie. Wynika to z listu Urbana V do arcybiskupa gnieźnieńskiego, w którym papież żąda, by ,...przywileje i doku-

1 Por. St. Krzyżanowski, Poselstwo Kazimierza Wielkiego do Awinionu $i$ pierwsze uniwersyteckie przywileje, „Rocznik Krakowski”, 4 (1900) 55 nn. Tamże teksty (łacińskie i polskie) pozostałych dokumentów związanych z założeniem uniwersytetu w Krakowie. 
menty króla i miasta pieczęciami opatrzone przysłać się postarał, abyśmy co do nadania wspomnianych przywilejów i swobód uzyskawszy pewność w tej sprawie stanowczo postąpić mogli..." 2 Jest to dowodem, że papież Urban był zainteresowany prawami, które miały być wydane dla nowo zakładanego uniwersytetu. $\mathrm{Na}$ podstawie dokumentów króla i miasta Urban V dnia 1 września 1364 r. zatwierdza fundację królewską. W parę dni po wydaniu zatwierdzenia dla studium generalnego w Krakowie, papież wysyła 13 września list do króla Kazimierza, przypominając raz jeszcze o postanowieniach zawartych $\mathrm{w}$ treści zatwierdzenia.

Przedstawiłem tu wszystkie akta i dokumenty związane $z$ powstaniem uniwersytetu krakowskiego. Odnośnie innych uniwersytetów nie mamy tylu tekstów źródłowych. Nie możemy stwierdzić z całą stanowczością, że ich nigdy nie było. Jest wszakże rzeczą co najmniej prawdopodobną, że tak ważne i doniosłe przedsięwzięcie jak założenie studium generalnego było dokonane na podstawie uprzedniej pisemnej prośby, a na pewno ustnej. Jeśli zaś były supliki pisemne, to zapewne uzupełniono je uzasadnieniem szczegółowym.

Wspomniałem już wcześniej o tym, że zatwierdzenia papieskie uniwersytetów w Pradze, Krakowie, Wiedniu, Pécsu, Heidelbergu i Chełmnie są do siebie podobne. Nasuwa się przeto pytanie, czy pomiędzy wspomnianymi tekstami zachodzi związek genetyczny, ewentualnie czy istniejące różnice i podobieństwa w redakcji poszczególnych zatwierdzeń pozwolą na ustalenie takiego związku. Dokumenty papieskie mają zewnętrzną budowę identyczną. Zawsze w tym samym porządku występują następujące części dokumentów: (1) intytulacja - czyli imię i tytuł wystawcy, (2) przytoczenie formuły ,ad perpetuam”, następnie (3) arenga - wyrażająca ogólną sentencję, dalej (4) „narracja” - opisanie wydarzeń, które poprzedziły wydanie papieskiego zezwolenia na działanie uniwersytetu, z kolei (5) ,dyspozycja” wyrażała wolę wystawcy dokumentu z podaniem okolicznośei uwzględnionych przy wystawianiu aktu oraz powołanie do życia uniwersytetu jak też (również $w$ dokumencie papieskim) zajęcia się sprawą przeprowadzenia egzaminu na doktorów i mistrzów, wreszcie (6) w części końcowej „,sankcja” zawierająca grożbę za naruszenie postanowień dokumentu, a (7) „datio" podawało datę wystawienia dokumentu. W jednym wypadku został naruszony wspomniany porządek. W zatwierdzeniu uniwersytetu w Pécsu przed sankcją występuje klauzula, w której papież pod groźbą unieważnienia zatwierdzenia zobowiązuje obecnego monarchę węgierskiego do zapewnienia doktorom i mistrzom odpowiedniego uposażenia (por. niżej s. 26).

2 Tamże, s. 88. Tekst łaciński tegoż cytatu brzmi (tamże, s. 59): - concessione privilegorium et libertatum huiusmodi confecta ipsorum regis et universitatis sigillis munita fideliter destinare procures, ne exinde habita certitudine predictorum in huiusmodi negocio tutius procedere valeamus. 
Przystępując do dokładniejszej analizy badanych papieskich zatwierdzeń uniwersytetów środkowoeuropejskich sporządziłem zestawienie odrośnych tekstów. Za podstawę przyjąłem tekst najstarszy, tzn. zatwierdzenie uniwersytetu w Pradze. Sporzadzając poniższe zestawienie staralem się uwzględnić odmianki lekcyjne, nawet nie mające żadnego znaczenia pod względem treści, a polegające na przykład na różnicach ortograficznych, jak suprema - supreme (s. 21), opportune - oportune (tamże). Oprócz tego wynotowałem także różnice stylistyczne przejawiające się tylko w innym szyku tych samych słów lub wyrażeń, np. Dominici gregis - gregis dominici (tamże). Występują również różnice między zdaniami lub ich częściami, lecz są to tak małe rozbieżności, iż pod względem merytorycznym nie wprowadzają niczego nowego. Oto przykład ze s. 23 :

- ad ipsorum, sed etiam aliorum regionum circumiacentium incolarum

- ad ipsorum ducatus et ville sed etiam regionum circumiacentium incolarum

- ad ipsorum regni et civitatis sed etiam regionum circumiacentium incolarum

- ad ipsium ville, sed etiam regionum circum adiacentium incolarum

- ad ipsius oppidi regionum circum adiacentium incolarum.

Inny rodzaj różnic tekstowych wynika z różnorodności wystawców danych dokumentów, odbiorców, państwa i miasta, dla którego papież wyrażał swoją zgodę. Jak wiadomo, wystawcą omawianych zatwierdzeń nie był jeden papież. Zatwierdzenie dla uniwersytetu praskiego wydaje Klemens VI. Zatwierdzenie dla studium generale w Krakowie, Wiedniu i Pécsu wystawia Urban V. Dwa dalsze zatwierdzenia wychodzą z kancelarii papieża Urbana VI. Różni są również odbiorcy zatwierdzeń. W pierwszym wypadku jest to król Czech Karol IV. Odbiorcą zatwierdzenia uniwersytetu krakowskiego jest król polski Kazimierz. Dalej w porządku chronologicznym odbiorcami tych dokumentów byli: Rudolf książę Austrii, król Ludwik węgierski, książę Bawarii Rupert i wreszcie wielki Mistrz - niewymieniony w dokumentach imiennie Konrad Zöllner von Rotenstein wraz z braćmi Zakonu Krzyżackiego. Dalsze różnice występujące między poszczególnymi tekstami wynikają z charakteru miasta, w którym papież zatwierdza uniwersytet. W dokumentach papieskich inaczej traktowane jest miasto - stolica biskupia, a inaczej miasto, w którym nie było biskupstwa, jak np. w Wiedniu i Heidelbergu. W takim wypadku kancelaria papieska oznaczała diecezję, do której należało dane miasto, przy czym na określenie takiej miejscowości używano terminu „villa” (por. s. 23), zatrzymując „civitas” jako nazwę stolicy biskupiej. Wyjątkiem od tej zasady jest „oppidum" na określenie Chełmna, chociaż w mieście tym rezydował biskup. 
Omówione różnice można uszeregować w dwu grupach. Pierwsza obejmuje odmianki literowe lub stylistyczne. Ta grupa różnic mogła powstać bądź przez nieuwagę pisarza sporządzającego dokument, albo tėz piszący bądź kopiujący zatwierdzenie korzystał z innego podobnego dokumentu i dokonywał zmian stylistycznych - w jego mniemaniu - stosowniejszych lub ładniejszych. Do drugiej grupy zaliczyłbym różnice wynikające z obiektywnie istniejących odmienności związanych z osoba wystawcy, osobą odbiorcy dokumentu, z państwem lub miastem, dla którego papież wyraża zgodę na powstanie uniwersytetu.

Dwie dalsze grupy różnic w omawianych tekstach ukazują istotne odmienności w strukturze poszczególnych studiów generalnych oraz główne rozbieżności między tekstami zatwierdzeń. Na tej podstawie możemy stwierdzić, że papieże, wyrażając zgodę na powstanie danego studium generalnego, wprowadzali takie postanowienia do tekstu zatwierdzeń, które w sposób zasadniczy różniły nowo powstające uniwersytety. I tak w zatwierdzeniu uniwersytetu w Pradze papież Klemens VI wyraża zgodę na działanie tego uniwersytetu ze wszystkimi wydziałami, bez ich wyszczególnienia. Inaczej postapił Urban V. Wbrew suplice króla Kazimierza, który prosił o studium generale ze wszystkimi możliwymi wydziałami, papież zatwierdzając fundację królewską wyraźnie zakazał uruchomienia wydziału teologicznego. Stąd uniwersytet krakowski w pierwszym okresie swego istnienia nie posiadał wszystkich wydziałów. Nie otrzymały również pozwolenia na działanie wydziału teologicznego studia generalne w Wiedniu i Pécsu. Uniwersytety w Heidelbergu i w Chełmnie otrzymały od Urbana VI zgodę na działanie wszystkich fakultetów, a w tym i wydziału teologicznego z wyraźnym wyrażeniem zgody na działanie tego ostatniego fakultetu. Zatwierdzając studium generalne w Heidelbergu, Urban VI wyraził zgodę na fundację księcia Bawarii Ruperta na wzór studium paryskiego, natomiast uniwersytet che1miński miał być zgodnie z papieską sugestią wzorowany na studium bolońskim.

Najbardziej interesująca jest czwarta grupa różnic zachodzących między wspomnianymi zatwierdzeniami. Dotyczą one - moim zdaniem motywów zgody papieskiej na działanie danego studium generale. Z uwagi na ważność problemu przytaczam poniżej (s. 22) całe teksty odpowiedniego fragmentu papieskiego zatwierdzenia dotyczącego każdego studium generalnego z osobna. Jak wspomniałem wcześniej, omówione zatwierdzenia papieskie posiadają identyczne części dokumentu, występujące zawsze w tym samym porządku. Wspomniana grupa różnic znajduje się w tzw. „narracji”. „Narracja” to opisanie wcześniejszych okoliczności poprzedzających promulgację dokumentu, a w naszym przypadku to opis wydarzeń wyprzedzających wydanie papieskiego zatwier- 
dzenia. Te okoliczności wstępne nie mogą być jednakowe w każdym wypadku. Nie ulega wątpliwości, że przed wydaniem papieskiego zatwierdzenia musiały między kurią papieską a fundatorem każdego z badanych studiów generalnych istnieć kontakty odnośnie do założenia uniwersytetu. Jest również pewne, że każdy z zainteresowanych założycieli uniwersytetu chciał uzyskać na to zgodę papieską, przedstawiając takie okoliczności, które by uzasadniały wystawienie papieskiego zatwierdzenia. Należy przypuszczać, że właśnie te motywy zostały $\mathrm{z}$ kolei powtórzone w dokumencie papieskim. Na fakt, iż owe motywy zostały wcześniej przedstawione papieżowi, wskazują słowa występujące na początku ,narracji”: w tekście praskim — „nobis exposito”, krakowskim — „nobis fuit expositum", a w pozostałych zatwierdzeniach — ,fuit propositum”. Jak wykazało sporządzone poniżej zestawienie badanych papieskich dokumentów, nie możemy mówić o zupełnej różnorodności motywów służących do poparcia prośby fundatora. „Narracja” papieskiego zatwierdze-nia uniwersytetu w Pécsu wzorowana jest na tekście dokumentu wiedeńskiego, a ,narracja" zatwierdzenia studium generalnego w Chełmnie oparta jest na ,narracji” zatwierdzenia uniwersytetu w Heidelbergu. Te podobieństwa wskazują na istnienie związku genetycznego między poszczególnymi tekstami lub pozwalają na przypuszczenie, że między państwami istniały ożywione kontakty, a doświadczenia jednego państwa były wykorzystywane przez inne państwa. Przez związek genetyczny rozumiem oparcie wszystkich wspomnianych papieskich zatwierdzeń na jednym formularzu. Takim formularzem mógł być wcześniejszy tekst zatwierdzenia nie objęty przedstawionymi przeze mnie dokumentami lub jedno $z$ badanych zatwierdzeń. Nie można również wykluczyć tej ewentualności, że takim formularzem mogły być dwa wcześniejsze zatwierdzenia. Omawiane papieskie zatwierdzenia studiów generalnych w Pradze, Krakowie, Wiedniu, Pécsu, Heidelbergu i Chełmnie korzystały z jednego formularza, a wobec tego między wspomnianymi zatwierdzeniami zachodzi związek genetyczny.

Analizując zebrane różnice dochodzimy do wniosku, że większe podobieństwa zachodzą między zatwierdzeniem krakowskim a analogicznymi dokumentami erekcyjnymi późniejszych uniwersytetów, niż między tekstem praskim a pozostałą grupą dokumentów papieskich. Wobec tego należy teraz rozstrzygnąc kwestię ewentualnego stosunku zachodzącego między zatwierdzeniem praskim i krakowskim. Stosunek ten mógł być dwojakiego rodzaju: albo oba teksty korzystały z tego samego wzorca, przy czym tekst praski był tu egzemplarzem pośrednim dla dokumentu krakowskiego, albo też zatwierdzenie krakowskie wzoruje się na zatwierdzeniu praskim, wprowadzając jednak nowe elementy.

Największy wpływ wywarło zatwierdzenie krakowskie na dwa chro- 
nologicznie najbliższe zatwierdzenia, wydane przez tego samego papieża Urbana $V$, tzn. na redakcję zatwierdzenia uniwersytetu $w$ Wiedniu i w Pécsu. Z kolei papieskie zatwierdzenie uniwersytetu w Pécsu jest niewątpliwie bardzo zbliżone do zatwierdzenia studium generale w Wiedniu, wykazujac jednocześnie wiele podobnych cech do zatwierdzenia. krakowskiego. Ustalając dalej stosunek między tymi zatwierdzeniami, doszedłem do wniosku, iż na dokumencie zatwierdzającym uniwersytet w Wiedniu oparło się zatwierdzenie uniwersytetu w Heidelbergu, które z kolei stanowiło podstawę zatwierdzenia uniwersytetu w Chełmnie. Graficznie stosunek genetyczny papieskich zatwierdzeń studiów generalnych w Pradze, Krakowie, Wiedniu, Pécsu, Heidelbergu i Chełmnie przedstawia się następująco:
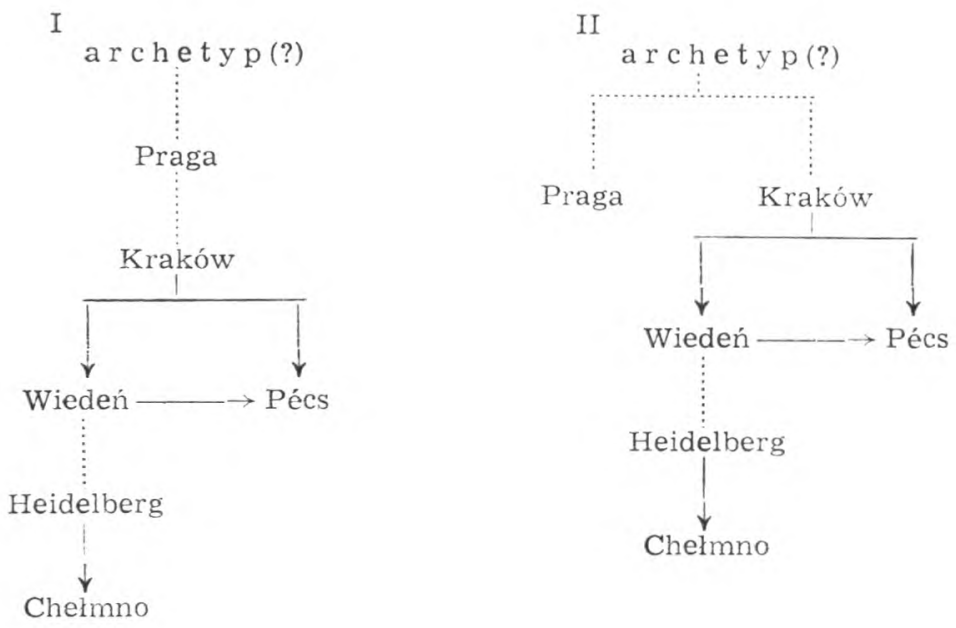

Kończąc powyższe wywody można by postawić hipotezę, iż wszystkie papieskie zatwierdzenia zostały oparte na jednym formularzu oraz, że zatwierdzenie krakowskie, wzorowane częściowo na dokumencie praskim, było wzorem dla zatwierdzeń studiów generalnych w Wiedniu i w Pécsu, a tym samym pośrednio dla dwóch pozostałych dokumentów papieskich. Chciałbym jednak zwrócić uwagę, że zachodzący stosunek genetyczny między tekstami papieskich zatwierdzeń nie może oznaczać oparcia się tylko na wspólnym formularzu. Można by takiej hipotezie zarzucić to, iż kancelaria papieska posiadała jeden formularz zatwierdzeń, który stosowała w każdym przypadku. Byłoby to dużym uproszczeniem omawianego problemu. Istniejący stosunek genetyczny między papieskimi dokumentami jest jedynie odzwierciedleniem podobieństwa całej akcji danego fundatora w uzyskiwaniu zezwolenia na założenie studium generale 
w swoim państwie. Podobieństwa i różnice między papieskimi dokumentami mogą wskazywać, jak dalece wykorzystano przykład wcześniejszy w uzyskaniu papieskiej zgody na uruchomienie kolejnego uniwersytetu.

\section{WNIOSKI}

Jak wiadomo, w ścisłym związku z ,narracją" pozostaje tzw. ,petitio", tj. przytoczenie prośby. Wyłania się wobec tego pytanie, czy ta część „,narracji” zatwierdzeń papieskich, w której przytoczono wcześniejsze na ten temat informacje, nie stanowi właśnie przytoczenia prośby. Oznaczałoby to, iż kancelaria papieska w zatwierdzeniu uwzględniała uzyskane wcześniej informacje, jak również przedstawiała wszelkie motywy służące do poparcia prośby zainteresowanego fundatora. Rolę prośby fundatora spełnia - o czym wcześniej wspomniałem - suplika. Sumując przedstawiony tok rozumowania, można postawić hipotezę, iż w ,narracji” papieskich zatwierdzeń znajdziemy o ile nie wiernie przytoczoną, to co najmniej streszczoną suplikę fundatora. Widać to z konfrontacji supliki króla Kazimierza z tą częścią tekstu zatwierdzenia papieskiego, w której można znaleźć motywy uzasadniające wystawienie dokumentu przez kancelarię papieską:

[CASIMIRI REGIS POLONIAE SUPPLICA AD URBANUM PP. V

Oblatum Avinione, die VI Aprilis A.D. $1363]^{3}$

- Item ut in civitate Cracoviensi insigniori regni sui studium generale in quacumque facultate et specialiter tam iuris canonici quam civilis erigere valeat cum privilegiis aliorum studiorum generalium, potissime cum propter magnam distanciam studiorum generalium, ultra XL dietas distancium sciencia in illis partibus exilium paciatur et multi nobiles clerici de Polonia aliqui capti et alij detenti, et in captivitate mortificati sunt et fuerunt. - -
[URBANI PP. V STUDII GENERALIS CRACOVIENSIS A CASIMIRO REGE POLONIAE INSTITUTI CONFIRMATIO

Datum Avinione, die I Septembris A. D. 1364$]^{4}$

- Cum itaque sicut nuper pro parte carissimi in Christo filii nostri $\mathrm{Ca}$ simiri regis Poloniae illustris, nobis fuit expositum, civitas sua Cracoviensis, quae in regno suo Poloniae consistit et insignior est aliis civitatibus dicti regni, a studiis generalibus nimium distare noscatur, et propterea iurisperitorum et literatarum personarum copia in eodem regno minime habetur, multique ex clericis nobilibus dicti regni eundo ad studia generalia huiusmodi capti, alii vero in captivitate detenti morti traditi fuerint. - -

Wniosek, jaki można wyciągnąć z porównania tych dwu tekstów, nie potwierdza pierwszej części przytoczonej wyżej hipotezy. Nie możemy bowiem w tym wypadku mówić o dokładnym powtórzeniu supliki kró-

s Tamże, s. 55 .

- Tamże, s. 68. 
lewskiej w zatwierdzeniu papieskim. Można jednak śmiało bronić drugiej części hipotezy, iż suplika wpłynęła na redakcję papieskiego zatwierdzenia, że w dokumencie papieskim znajdziemy odzwierciedlenie prośby fundatora.

Spróbuję obecnie przedstawić te motywy, którymi kierowało się papiestwo w wyrażeniu zgody na powstanie innych studiów generalnych. Zacznę od najwcześniej założonego $\mathrm{z}$ omawianych uniwersytetów, studium generalnego w Pradze. Dokument papieski w tym wypadku wyprzedza akt fundacyjny Karola IV. Na pozór oznaczałoby to, iż z inicjatywą występuje tutaj sam papież. Jest to niemożliwe, zważywszy początek „narracji”, a więc na owe wcześniejsze okoliczności wyprzedzające wydanie papieskiego dokumentu. Znajdujemy tu następujące słowa: ,... pro parte carissimi in Christo filii nostri Caroli, regis Romanorum illustris, nobis exposito, quod in hereditario regno suo Boemie...". Następnie ma miejsce wyliczenie tych wszystkich okoliczności, które przemawiają za tym, aby właśnie w Czechach, w mieście Pradze powstało studium generalne. Czy jest możliwe, by papież te wszystkie okoliczności przytaczał w swoim dokumencie, nie mając wcześniej przedłożonej pisemnej lub przynajmniej ustnej prośby? Z porównania motywów, jakimi kierowali się papieże w wyrażaniu swej zgody na działanie uniweısytetu w Pradze i w Krakowie, widać większą ilość i różnorodność okoliczności, przemawiających za powstaniem uniwersytetu w Pradze. Nie zapominajmy jednak o tym, że uniwersytet $\mathrm{w}$ Pradze najpierw otrzymał papieskie zatwierdzenie, a dopiero później akt erekcyjny Karola IV. Papież w tym wypadku zatwierdzał uniwersytet, nie znając jeszcze dokładnie treści przywilejów nowo zakładanego uniwersytetu.

Inaczej było w przypadku Uniwersytetu Krakowskiego. Urban V nie tylko, że posiadał w ręku suplikę królewską, ale również listem skierowanym do arcybiskupa gnieźnieńskiego żądał informacji o mieście Krakowie oraz przesłania mu aktu fundacyjnego króla Kazimierza i dyplomu miasta Krakowa, poręczającego prawa uniwersytetu. Dopiero na podstawie tych dokumentów dnia 1 września $1364 \mathrm{r}$. zatwierdza powstanie uniwersytetu krakowskiego. O tym, że papież wydając zatwierdzenie znał treść dokumentu królewskiego świadczy list skierowany 13 IX 1364 r. przez papieża Urbana V do króla Polski Kazimierza. W liście tym papież wspomina o akcie fundacyjnym wydanym przez Kazimierza Wielkiego, jak również o tym, że treść tego dokumentu jest mu znana.

Z analizy części „narracji” papieskich dokumentów dotyczących założenia uniwersytetów w Wiedniu i w Pécsu, w której znajdujemy okoliczności skłaniające papieża Urbana $\mathrm{V}$ do wyrażenia zgody na powstanie tych uczelni wynika, że w obydwu wypadkach motywy decyzji były identyczne. Na początku każdej „narracji” znajdujemy sformułowanie 
wskazujące, że prośby fundatorów zostały przedłożone wobec papieża na konsystorzu (fuit propositum in consistorio coram nobis). W dalszej kolejności następuje bardzo ogólnikowe wyliczenie motywów. Ta ogólnikowość mogła być spowodowana istnieniem mało szczegółowej supliki albo tė tylko ustnym przedstawieniem prośby fundatorów. W tych wypadkach mogła powtórzyé się podobna sytuacja jak przy zakładaniu Uniwersytetu Krakowskiego. $\mathrm{Na}$ istnienie podobieństwa wskazuje ścisły związek genetyczny, zachodzący między papieskimi zatwierdzeniami. Prawdopodobnie w obydwu wypadkach istniały supliki pisemne lub przynajmmiej ustne przedłożenie prośby, stanowiące początek starań królewskich o założenie danego uniwersytetu. Z kolei zostały wydane akty fundacyjne, przesłane papieżowi. Na podstawie tych dokumentów papież Urban $V$ zatwierdził fundację uniwersytetów w Wiedniu i w Pécsu. Jakkolwiek wśród dokumentów dotyczacych powstania uniwersytetu w Pécsu posiadamy tylko jego papieskie zatwierdzenie, co powoduje że przeprowadzenie tej analogii jest w dużym stopniu utrudnione. Mamy jednak powody, by przypuszczać, że istniał również akt fundacyjny tego studium. Wskazuje na to list papieża Urbana V do króla Węgier Ludwika, opatrzony datą 2 września 1367 r. Podobny - jak pamiętamy — zostal skierowany przez tego samego papieża do króla polskiego Kazimierza. W liście do króla Ludwika Urban V również wspomina o wydanym wcześniej akcie fundacyjnym oraz o tym, że treść tego aktu jest mu znana. Można się także pośrednio dopatrzeć dowodu o istnieniu aktu fundacyjnego uniwersytetu w Pécsu w tym, że papież nie znajdując w akcie fundacyjnym odpowiedniego uposażenia finansowego dla uniwersytetu, wprowadza w swoim zatwierdzeniu odpowiednią wzmiankę. Takie samo postanowienie o uposażeniu zostało powtórnie umieszczone we wspomnianym liście. Natomiast nie czyni tego Urban $\mathrm{V}$ w stosunku do uniwersytetu wiedeńskiego, którego dokument fundacyjny w sposób wyczerpujacy przedstawia prawa i przywileje powstającego studium generalnego. Widzimy więc, że założenie uniwersytetu w Krakowie stało się przykładem dla później powstających uniwersytetów, a w szczególności dla studiów generalnych w Wiedniu i w Pécsu.

Założenia dwóch ostatnich uniwersytetów w Heidelbergu i Chełmnie nie można włączyć do grupy uniwersytetów pozostających pod silnym wpływem powstania uniwersytetu w Krakowie. Łączy się to z pewnościa ze śmiercią papieża Urbana V. Niewątpliwie i w tych wypadkach istniały supliki pisemne bądź prośby ustne. Potwierdzenie tego faktu znajdujemy w zatwierdzeniach papieskich, dotyczących tych uniwersytetów. $\mathrm{Na}$ początku identycznych w obu wypadkach ,narracji” znajdujemy podobne jak w pozostałych zatwierdzeniach sformułowanie (fruit propositum coram nobis). Jednocześnie pierwszy rektor uniwersytetu w Heidel- 
bergu Marsilius de Inghen, opisując starania związane z założeniem tamtejszego studium generale, wspomina o istnieniu supliki. Wiadomo, że zatwierdzenie papieskie dotyczące uniwersytetu w Heidelbergu wyprzedza akt fundacyjny, który został wydany w rok później przez księcia Bawarii Ruperta. Można wobec tego przypuszczać, że przykładem dla powstania uniwersytetu $w$ Heidelbergu było założenie studium generalnego w Pradze. Wobec tego papież Urban V wydając swoje zatwierdzenie dla uniwersytetu w Heidelbergu, opiera się tylko na suplice, nie znając aktu fundacyjnego księcia Ruperta. Mając na uwadze to, iż zatwierdzenie uniwersytetu w Heidelbergu stanowiło wzór dla uniwersytetu w Chełmnie, dochodzimy do stwierdzenia, że suplika musiała istnieć i w tym wypadku. Nie wiadomo natomiast, czy akt fundacyjny dla uniwersytetu w Chełmnie został później wydany przez Zakon Krzyżacki, gdyż nie mamy żadnych śladów, aby ten uniwersytet kiedykolwiek rozpoczął swą działalność.

Kończąc omawianie papieskich zatwierdzeń uniwersytetów w Pradze, Krakowie, Wiedniu, Pécsu, Heidelbergu i Chełmnie, chciałbym raz jeszcze podkreślić rolę i znaczenie, jakie odegrało założenie uniwersytetu kazimierzowskiego w historii powstania uniwersytetów w środkowej Europie w latach 1347-1386 r. Chociaż uniwersytet krakowski należał do grupy studiów generalnych w Pradze, to należy pamiętać o tym, że powstanie uniwersytetu krakowskiego stanowiło bezpośredni wzór dla powstania uniwersytetów w Wiedniu i Pécsu, a tym samym wywarło pośredni wpływ na powstanie uniwersytetów w Heidelbergu i Chełmnie. W ten sposób powstanie uniwersytetu krakowskiego stanowi ważne ogniwo w procesie zakładania uniwersytetów europejskich, wchodząc na trwałe w dzieje kultury ogólnoludzkiej. 


\section{[CONFIRMATIO STUDII GENERALIS PRAGENSIS A CLEMENTE PP. VI PERMISSA *]}

Clemens ${ }^{a}$ episcopus servus servorum Dei. Ad perpetuam rei memoriam. In suprema ${ }^{b}$ dignitatis apostolice ${ }^{c-}$ specula, quamquam insufficientibus meritis, divine dispensationis munere-d constituti, ad universas fidelium regiones ${ }^{\mathrm{e}-\mathrm{e}}$ eorumque ${ }^{\mathrm{f}}$ profectus et commoda, tamquam $\mathrm{g}-$ universalis Dominici gregis $^{-\mathrm{h}}$ pastor, comisse $^{\mathrm{i}}$ nobis speculationis aciem, quantum ${ }^{j}$ nobis ex alto permittitur, extendentem, fidelibus ipsis ad querenda literarum ${ }^{\mathrm{k}}$ studia per que divini nominis sueque ${ }^{1 \mathrm{~m}}$ - catolice fidei ${ }^{-n}$ cultus protenditur, iustitia ${ }^{\circ}$ colitur, tam publica quam privata res ${ }^{p-g e r i t u r ~ u t i l i t e r ~}{ }^{-q}$ omnisque prosperitas hamane conditionis augetur, $r-$ gratiosos libenter favores $^{-\mathrm{s}}$ impedimus et opportune ${ }^{t}$ commoditatis auxilia ${ }^{\mathrm{u}-\mathrm{u}}$ impartimur ${ }^{\mathrm{v}}$.

* Huius bullae textum (ed. in: Monumenta Historica Universitatis Carolo-Ferdinandae Pragensis. II 2: Codex Diplomaticus Universitatis Pragensis [...], Pragae 1834, 219-222) exemplar principale comparationi nostrae similium confirmationum papalium accommodatum usurpavimus. Quae quidem pertinent ad Studium Generale:

C - Culmense (Chełmno); ed. in: Urkendenbuch des Bisthums Culm, bearb. von C. P. W o elk y, Danzig 1884, 289 sq. (nr 369).

$\mathrm{H}$ - Heidelbergense (Heidelberg); ed. in: Urkunden亏uch der Universität Heidelberg, bearb. von E. W in k e $1 \mathrm{~m}$ a n n, Heidelberg 1866, p. 3 sq.

$\mathrm{K}$ - Cracoviense (Kraków); ed. in: Codex Diplomaticus Universitatis Studii Generalis Cracoviensis 1, Cracoviae 1870, 6 sq.

$\mathrm{P}$ - Quinqueecclesiarum (Pécs); ed. in: Codex diplomaticus Hungariae ecclesiasticus et civilis IX 4, Budae 1834, p. 65-68.

$\mathrm{W}$ - Viennense (Wien); ed. in: R. K in k, Geschichte der kaiserlichen Universität zu Wien II, Wien 1854, p. 26-28.

a Urbanus $K W P H C$

b supreme WPHC

c-d licet immeriti disponente domino $K W P$, superni dispensatione consilii licet immeriti $\mathrm{HC}$

e-e nostre vigilantie creditas $H$, nobis creditas $C$

$f$ eorum $P$

$\mathrm{g}-\mathrm{h}$ gregis dominici $\mathrm{W} P \mathrm{HC}$

i commissi $H$

j quanto $P$

k. litterarum $H$

1 fideique $H$

$\mathrm{m}-\mathrm{n}$ fidei catholice $K W P C$, catholice $H$

$\circ$, iusticia $H$

$\mathrm{p}-\mathrm{q}$ utiliter geritur $K$

r-s. libenter favores gratiosos $K W P H C$

$t$ oportune $W H$

$u-u$ liberaliter $K W P H C$.

v impertimur $K W$ P HC 
a- Nuper siquidem pro parte carissimi in Christo filii nostri Caroli, regis Romanorum illustris, nobis exposito, quod in hereditario regno suo Boemie, multisque aliis eidem regno finitimis regionibus atque terris, generale studium, quod in illis partibus summe foret expediens, non habetur quodque metropolitica Pragensis civitas, in ipsius regni medio locoque saluberrimo sita et a diversarum partium gentibus frequentata, ac in victualibus aliisque vite necessariis copiosa, ad huiusmodi generale erigendum, cum particulare dudum in ea fuerit studium, accommoda multum existeret ${ }^{-b}$; $c-$ nos considerantes eximiam devocionis et $-\mathrm{d}$

$a-b$ Cum itaque sicut nuper pro parte carissimi in Christo filii nostri Casimiri regis Polonie illustris nobis fuit expositum, civitas sua Cracoviensis, que in regno suo Polonie consistit et insignior est aliis civitatibus dicti regni, a studiis generalibus nimium distare noscatur et propterea iurisperitorum et literatarum personarum copia in eodem regno minime habeatur multique ex clericis nobilibus dicti regni eundo ad studia generalia huiusmodi capti, alii vero in captivitate detenti morti traditi fuerint $K$;

Cum itaque sicut nuper pro parte dilecti filii nobilis viri Rudolphi ducis Austrie fuit propositum in consistorio coram nobis, ipse dux non solum ad utilitatem et prosperitatem huiusmodi rei publice et incolarum ducatus sui Austrie, sed etiam aliorum partium vicinarum laudabiliter intendens, in villa sua Viennensi, Patavienensis diocesis, in ducatu predicto consistente tanquam insigniori et magis ad hoc accomoda et idonea, plurimum desideret fieri et ordinari per sedem apostolicam studium generale in qualibet licita facultate, ut ibidem fides ipsa dilatetur, erudiantur simplices, equitas servetur, iudici crescat ratio et intellectus hominum augeatur $W$;

Cum itaque sicut nuper pro parte carissimi in Christo filii nostri Lodovici regis Hungarie illustris fuit propositum in consistorio coram nobis, ipse rex non solum ad utilitatem et prosperitatem huiusmodi rei publice et incolarum regni Hungarie, sed etiam aliarum partium vicinarum laudabiliter intendens in civitate Quinqueecclesiensi in regno predicto consitente, tanquam insigniori et magis ad hoc accomoda et idonea, plurimum desideret fieri et ordinari per sedem apostolicam studium generale in qualibet licita facultate, ut ibidem fides ipsa dilatetur erudiantur simplices, equitas servetur, iudicii crescat ratio et intellectus huiusmodi augeatur $P$;

Cum itaque sicut nuper pro parte dilecti filii, nobilis viri Ruperti senioris ducis Bavarie, palatini Reni, fuit propositum coram nobis, ipse dux non solum ad utilitatem et prosperitatem huiusmodi rei publice ad ac incolarum terrarum sibi subiectarum, sed etiam aliarum partium vicinarum laudabiliter intendens in villa sua Heidelberg Vormatiensis diocesis in dominio suo consistente tanquam insigniori et magis ad hoc accomoda et idonea, in qua aeris viget temperies, victualium ubertas ceterarumque rerum ad usum humanum pertinentium copia reperitur, desideret plurimum fieri et ordinari per sedem apostolicam studium generale in qualibet licita facultate, ut ibidem fides ipsa dilatetur, erudiantur simplices, equitas servetur, iudicii vigeat ratio, illuminentur mentes et intellectus hominum illustrentur $H$;

Cum itaque nuper pro parte dilectorum filiorum Magistri et fratrorum hospitalis beatae Mariae Theotonicorum Jerlimitani fuit propositum coram nobis, quod ipsi Magister et fratres non solum ad utilitatem et prosperitatem huiusmodi reipublice ac incolarum terrarum eis subiectarum sed etiam aliarum partium vicinarum laudabiliter intendens in eorum opido Culmen Culmensis diocesis tanquam insigniori et magis ad hoc accomodo et ydoneo, in quo aeris viget temperies, victualium ubertas et exterarum rerum ad usum humanum pertinentium copia reperitur desiderat plurimum, fieri et ordinari per sedem apostolicam studium generale in qualibet licita facultate, ut ibidem fides ipsa dilatetur, erudiantur simplices, aequitas servetur iudicii vegeat ratio, illuminentur mentes et intellectus hominum illustrentur $C$

c-d premissa ac (et $H$ ) etiam eximiam $K W P$, premissa ac eorum et etiam eximiam $C$ 
a- fidei puritatem ${ }^{-b}$, c- quam tam ipse Carolus et predecessores sui, Boemie reges, quam eiusdem regni incole $-d$ ad sanctam Romanam ecclesiam $\mathrm{e}^{-}$gessisse, ac ipsi Carolus rex et incole ${ }^{-\mathrm{f}}$ gerere dinoscun$\operatorname{tur}^{\mathrm{g}-\mathrm{g}}$ ferventi desiderio ducimur $\mathrm{h}-\mathrm{ut}$ regnum ipsum, quod divina bonitas multitudine populi rerumque copia predotavit, fiat literarum fertilitate fecundum ac in eo, quemadmodum auri et argenti fore dinoscitur, sic scientiarum prevalentium sit misera ${ }^{-i}$; ut vires producat $^{j}$ consilii maturitate conspicuos, virtutum redimitos ornatibus ac ${ }^{k}$ diversarum facultatum dogmatibus eruditos, sitque ibi ${ }^{1-1}$ fons irriguus ${ }^{m}$,

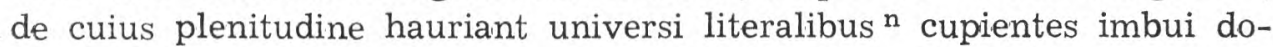
cumentis. His ${ }^{o}$ igitur omnibus et presertim $\mathrm{p}$-amoenitatibus civitatis prefato diligenti examinatione pensatis, ad huiusmodi universale $-q$ non $\mathrm{r}$-premissorum eiusdem regni et regionum circum adiacentium incolarum, sed etiam aliorum, qui de diversis mundi partibus ad eadem confluent civitatem $^{-\mathrm{s}}$ commodum et protectum ${ }^{\mathrm{t}}$.

$\mathrm{a}-\mathrm{b}$ et devotionis sinceritatem $\mathrm{WHC}$

$c-d$ tam ipse rex et progenitores sui Polonie quam eiusdem regni incole $K$, tam ipse dux quam progenitores sui duces Austrie $W$, tam ipse rex et progenitores sui Hungarie quam eiusdem regni incole $P$, ipse dux $H$, ipsi Magister et fratres $C$

e-f gesisse prout ipsi rex et incole $K P$, gesserunt prout ipse dux $W$, om. $H$, fidemque catholicam $C$

$g-g$ (dinoscitur $H$ ) attente considerantes $K P C$

$\mathrm{h}-\mathrm{i}$ quod regnum ipsum scienciarum muneribus amplietur fiatque literarum fertilitate fecundum $K$, quod ducatus et villa predicti scientiarum muneribus amplientur $W$, quod regnum ipsum scientiarum muneribus amplietur fiatque literarum fertilitate fecundum $P$, quod villa predicta scientiarum ornetur muneribus ita $H$, quod opidum praedictum scientiarum ornetur donis ita $C$

j producant $W$

k ad $C$

$1-1$ illi $P$, scientiarum $K W P H C$

$m$ originis $P$, irrigans $C$

n literarum $K W H C$, litterarum $P$

o hiis $\mathrm{HC}$

$\mathrm{p}-\mathrm{q}$ ydoneitate dicte civitatis que ad multiplicanda doctrine semina et germina salutaria producenda magis congrua et commoda inter alias civitates dicti regni fore dicitur, diligenti examinatione pensatis ad obviandum damnis et periculis verisimiliter proventuris ex distantia studiorum huiusmodi incolis dicti regni volentibus acquirere scientie margaretham et $K$;

idoneitate dicte ville que ad multiplicanda doctrine semina et germina salutaria producenda magis congrua et accomoda inter alias villas ducatus predicti fore dicitur diligenti examinatione pensatis $W$;

idoneitate dicte civitatis que ad multiplicanda doctrine semina et germina salutaria producenda magis accomoda et idonea inter alias civitates dicti regni fore dicitur diligenti examinatione pensatis $P$;

idoneitate dicte ville que ad multiplicanda sane doctrine semina et germina salutaria producenda magis congrua et accomoda inter alias villas dicioni predicti ducis subiectas fore dicitur diligenti examinatione pensatis $H$;

idoneitate dicti opidi, quod ad multiplicanda doctrine sane semina et germina salutaria producenda magis congruum et accomodum inter alia loca et opida ditioni predictorum Magistri et fratrum subiecta fore dicitur, diligenti examinatione pensatis $C$

$r-s$ ad ipsorum, sed etiam aliarum regionum circumiacentium incolarum $K$, ad ipsorum ducatus et ville, sed etiam regionum circumiacentium incolarum $W$, ad ipsorum regni et civitatis, sed etiam regionum circumiacentium incolarum 
paternis affectibus $\mathrm{a}-$ anhelantes, dicti regis ${ }^{-\mathrm{b}}$ supplicationibus inclinati $\mathrm{c}-$ de fratrum nostrorum consilio apostolica auctoritate ${ }^{-d}$ statuimus ${ }^{\mathrm{e}-\mathrm{e}}$, ut in $\mathrm{f}$ - dicta civitate Pragensi perpetuis futuris temporibus generale studium vigeat in qualibet licita ${ }^{-\mathrm{g}}$ facultate, $\mathrm{h}$ - et quod ${ }^{-\mathrm{i}}$ legentes et studentes ibidem omnibus privilegiis, libertatibus ac ${ }^{\mathbf{j}} \mathrm{immu-}$ tatibus concessis ${ }^{\mathrm{k}-\mathrm{k}}$ doctoribus, legentibus et studentibus commorantibus in $1-$ studio generali gaudeant et utantur quodque $-m$ illi, qui processu temporis $n-$ scientie margatitam fuerint -0 in illa facultate, in qua studuerint, assecuti $\mathrm{p}-\mathrm{p}$ sibique docendi licentiam, ut alios erudire valeant ac q-magisterii honorem seu titulum petierint impartiri, per magistros seu magistrum $^{-r}$ illius facultatis, in qua examinatio fuerint facienda,

$P$, ad ipsius ville, sed etiam regionum ricum adiacentium incolarum $H$, ad ipsius opidi, sed etiam regionum circum adiacentium incolarum $C$

t aptum $C$

a-b anelantes (anhelantes $K$ ) dicti regis in hac parte $P$, anelantes dicti ducis in hac parte $W$, anhelantes predicti necnon dilectorum filiorum nobilium virorum Ruperti iunioris et Ruperti preiunioris ducum Bavarie in hac parte $H$, anhelantes huiusmodi praedictorum Magistri et fratrum in hac parte $C$

c-d de fratrum nostrorum consilio aucthoritate apostolica $K W$, de fratrum nostrorum consilio $P$, ad laudem divini nominis et fidei propagationem orthodoxe auctoritate apostolica $H C$

e-e et eciam ordinamus $K W H C$, ac etiam ordinamus $P$

$\mathrm{f}-\mathrm{g}$ dicta civitate Cracoviensi de cetero sit studium generale illudque perpetuis temporibus inibi vigeat, tam in iuris canonici et civilis, quam alia qualibet licita, preterquam in theologia $K$, dicta villa de cetero sit studium generale illudque peretuis temporibus inibi vigeat, tam in iuris canonici et civilis, quam alia qualibet licita preterquam theologica $W$, dicta civitate Quinque Ecclesiensi de cetero sit studium generale ibique perpetuis temporibus inibi vigeat tam in iuris canonici et civilis, quam alia qualibet licita preterquam in theologica $P$, dicta villa de cetero sit studium generale ad instar Parisiensis illudque perpetuis temporibus inibi vigeat tam in theologia et iuris canonici quam alia qualibet licita $H$, eodem opido de cetero sit studium generale ad instar Studii Bononiensis illudque perpetuis temporibus inibi vigeat tam in theologia et iure canonioo quam alia qualibet licita $C$

$\mathrm{h}-\mathrm{i}$ quodque $\mathrm{HC}$

j et $K W P H C$

$\mathrm{k}-\mathrm{k}$ magistris in theologia ac $\mathrm{HC}$

$1-\mathrm{m}$ studio generali gaudeant et utantur quodque $P$, studio generali Parisiensi gaudeant et utantur et quod $H$, eodem studio Bononiensis gaudeant et utantur et quod $C$

$\mathrm{n} \rightarrow \mathrm{o}$ bravium fuerint $K P$, bravium meruerint $W H C$

$\mathrm{p}-\mathrm{p}$ obtinere $\mathrm{WHC}$

$q-r$ doctoratus seu magisterii honorem petierint elargiri, per doctores seu doctorem ac magistros seu magistrum $K W P$, magisterii seu doctoratus honorem petierint elargiri per magistrum seu magistros doctorem vel doctores $H C$ 
a- archiepiscopo Pragensi-b, qui est ${ }^{c}$ pro tempore ${ }^{d-d}$ presententur e- idem quoque archiepiscopus doctoribus et magistris ${ }^{-\mathrm{f}}$ in eadem facultate $\mathrm{g}$ - inibi actu ${ }^{-\mathrm{g}}$ regentibus convocatis, illos in his ${ }^{\mathrm{h}}$, i- que in promovendis $^{-j}$ ad $k-$ doctoratus seu magisteri $^{-1}$ honorem requiruntur, $\mathrm{m}^{-}$per se vel alium ${ }^{-\mathrm{n}}$ iuxta modum et consuetudinem, que ${ }^{\mathrm{o}}$ super talibus in generalibus studiis observantur, examinare studeat diligenter eisque si ad hoc sufficientes et idonei reperti fuerint, huiusmodi licentiam tribuat $\mathrm{p}-\mathrm{ac}$ honorem seu titulum conferat magistralem ${ }^{-\mathrm{q}}$. Illi vero, qui in eodem ${ }^{r}$ studio dicte ${ }^{s}$ civitatis $^{t}$ examinati et approbati fuerint ac docendi licentiam et honorem ${ }^{\mathrm{u}}$ - seu titulum magisterii ${ }^{\mathrm{v}} \mathrm{v}$ obtinuerint,

a-b episcopo Cracoviensi $K$, preposito ecclesie Omnium Sanctorum dicte ville W, episcopo Quinque Ecclesiensi $P$, preposito ecclesie Wormatiensis $H$, dilecto filio preposito ecclesie Culmensis $C$

c omm. KW P H C

d-d fuerit vel ecclesia Cracoviensi pastore carente, vicario seu officiali dilectorum filiorum capituli iosius ecclesie $K$;

fuerit vel prepositura ipsius ecclesie vacante, illi, qui ad hoc per dilectos filios capitulum eiusdem ecclesie deputatus fuerit $W$;

fuerit vel ecclesia Quinque Ecclesiensi pastore, carente vicario seu officiali dilectorum filiorum capituli ipsius ecclesie $P$;

fuerit vel eius sufficienti et idoneo, quem ad hoc idem prepositus duxerit deputandum, vicario prepositura vero ipsius ecclesie vacante illi, qui ad hoc per dilectos filios capitulum ipsius ecclesie deputatus extiterit $H$;

fuerit vel eius sufficienti et idoneo vicario, quem ad hoc idem prepositus duxerit deputandum praepositura vero ipsius ecclesie vacante, illi qui ad hoc per dilectos filios capitulum eiusdem ecclesie deputatus extiterit $C$

e-f idemque prepositus vel vicarius aut deputatus, ut prefertur, magistris et doctoribus $H$, idemque prepositus aut deputatus ut prefertur magistris et doctoribus $C$, idemque quoque episcopus aut vicarius seu officialis doctoribus et magistris $K P$, idem quoque prepositus aut deputatus, ut prefertur doctoribus et magistris $W$

$\mathrm{g}-\mathrm{g}$ actu inibi $K W P H C$

h hiis $\mathrm{HC}$

i-j circa promovendos $K W$ P H C

$\mathrm{k}-\mathrm{l}$ magisterii seu doctoratus $\mathrm{HC}$

$\mathrm{m}-\mathrm{n}$ per se vel per alium $K P$, omm. $H \mathrm{C}$

- qui $\mathrm{KWHC}$

p-q et doctoratus seu magisterii conferat honorem $K W P$, et magisterii seu doctoratus honorem conferat et etiam largiatur $H C$

r om. C

s dicti $C$

$\mathrm{t}$ ville $\mathrm{WH}$, opidi $\mathrm{C}$

$\mathrm{u}-\mathrm{v}$ huiusmodi $K \mathrm{~W} P \mathrm{HC}$ 
ut est dictum extunc absque examine ${ }^{a}$ et approbatione alia, regendi ${ }^{b}$ et ${ }^{c}$ docendi, tam in ${ }^{d-}$ civitate predicta $^{-\mathrm{e}}$, quam ${ }^{\mathrm{f}-}$ alibi ubicumque quibuscumque tam dicte civitatis, quam quorumlibet aliorum locorum, seu generalium studiorum ${ }^{-\mathrm{g}}$, in quibus voluerint, ${ }^{\mathrm{h}}$ - regere vel $^{-\mathrm{h}}$ docere, statutis vel $^{i}$ consuetudinibus $^{j-j}$ contrariis, apostolica vel alia ${ }^{k}$ quamcumque firmitate $^{1-1}$ vallatis ${ }^{m}$ nequaquam obstantibus, plenam et liberam habeant facultatem ${ }^{n-n}$.

Nulli ergo omnino hominum liceat hanc paginam nostre ${ }^{\circ}$ constitucionis ${ }^{p}$ infringere vel ei ausu temerario contraire. Si quis autem hoc attentare $^{q}$ presumpserit, indignationem omnipotentis Dei et beatorum ${ }^{r}$ Petri et Pauli apostolorum eius se noverit incursurum.

Datum s-Avenione septimo Kalendas Februarii pontificatus nostri anno quinto ${ }^{-t}$.

examinatione $P$

legendi $\mathrm{HC}$

atque $C$

d-c villa predicta $W H$, predicto ipsius oppido $C$

$\mathrm{f}-\mathrm{g}$ singulis aliis generalibus studiis $K W \mathrm{P}$, in singulis aliis generalibus studiis $H \mathrm{C}$

h-h legere vel $K$, legere et $H C$, regere $P$

i et $\mathrm{KWPHC}$

j-j quibuscunque $K W P H C$

k omm. KW P HC

1-1 alia $K W P$

m roboratis $H \mathrm{C}$

$n-n$ Volumus autem, quod magistris et doctoribus, qui in huiusmodi legent studio, per regem Ungarie pro tempore existentem in competentibus stipendis provideatur alioquin presentes littere nullius sint roboris vel momenti $P$

0 ordinationis $K$

$\mathrm{p}-\mathrm{p}$ et voluntatis $K$, et ordinationis $W H$, ordinationis et voluntatis $P$, constitutionibus et ordinationis $C$

q attemptare $\mathrm{KWPHC}$

r Beatorum $K$

s-t Avenione, Calendis Septembris, pontificatus nostri anno secundo $K$, Avinione, decimoquarto Kalendas Julii, pontificatus nostri anno tertio W, Viterbii, Kalendis septembris, pontificatus nostri anno quinto $P$, Ianue $\mathrm{X}$ kalendas novembris, pontificatus nostri anno octavo $H$, Ianue $V$ idus Februarii, pontificatus nostri anno octavo $\mathrm{C}$ 


\section{DIE PÄPSTLICHE BESTÄTIGUNG DER STIFTUNG DER MITTELEUROPÄISCHEN UNIVERSITÄTEN: $1347-1386$}

\section{Z U S A M M E N F A S S U N G}

Der im Jahre 1976 verstorbene Verfasser, ein Schüler des Professors Adam Vetulani ( $\dagger$ 1976), unternimmt einen Vergleich der päpstlichen Dokumente, welche die Bildung der Studia Generalia in Prag, Kraków, Wien, Pecs, Heidelberg und Chelmno (Kulm) betreffen.

In diesem Studium untersucht er die Frage der Ähnlichkeit und der Unterschiede im Vorgang der Entstehung der mitteleuropäischen Universitäten.

Andrzej Partyka gründet seine Arbeit auf die Analyse der Quellentexte, er benutzt keine andere Literatur. Die auf Grund einer im J. 1964 verfassten Maschinenschrift abgedruckte Arbeit hat eine anerkennende Bewertung vonseiten des Professors Adam Vetulani erhalten, der im J. 1970 eine ausführliche Monopraphie: „Die Anfänge der ältesten mitteleuropäischen Universitäten” veröffentlicht hatte.

Nach kurzen einleitenden Bemerkungen, in denen der Verfasser den Zweck und die Aufgaben der Arbeit anzeigt, verfolgt er dann den genetischen Zusammenhang zwischen den untersuchten Dokumenten und weist nach, dass diese Dokumente sich auf dasselbe Formular stützten. Er vertritt auch die Ansicht, dass die Krakauer Bestätigung, die sich teilweise an das Prager Dokument anlehnte, als Muster für die Bearbeitung der analogen Akte für Wien und Pecs, und auch für Heidelberg und Kulm gedient hat.

Die Feststellung dieser genetischen Verknüpfung dient dem Verfasser zur Begründung seiner These, die er in der Schlussfolgerung der Ausführungen ausdrückt, dass das im Jahre 1364 von König Kasimir dem Grossen gestiftete Krakauer Studium Generale eine entscheidende Rolle für die Gründung der mittelälterlichen Universitäten im XIV Jahrhundert gespielt hat. 